\title{
PENGARUH METODE INKUIRI TERHADAP KETERAMPILAN MENULIS BERITA SISWA KELAS VIII SMPN 9 PAYAKUMBUH
}

\author{
Oleh: Sufia Retti ${ }^{1}$, Rita Arianti ${ }^{2}$ \\ (STKIP Yayasan Abdi Pendidikan Payakumbuh ${ }^{1}$, Dosen STKIP Rokania ${ }^{2}$ ) \\ Email: Retti_sufia@yahoo.com ${ }^{1}, \underline{\text { ritaarianti935@gmail.com }{ }^{2}}$
}

\begin{abstract}
Abstrak
Tujuan penelitian ini untuk mendeskripsikan pengaruh metode inkuiri terhadap keterampilan menulis berita siswa kelas VIII SMP Negeri 9 Payakumbuh ditinjau dari kelengkapan unsur-unsur berita, EYD, dan kalimat efektif. Jenis penelitian ini adalah penelitian kuantitatif. Metode yang digunakan adalah eksperimen. Sampel penelitian ini adalah siswa kelas VIII.2 SMP Negeri 9 Payakumbuh. Secara umum nilai rata-rata pretest 71,5 dan nilai rata-rata posttest 80,3. Pada kelengkapan unsur berita nilai rata-rata pretest 96,59 dan nilai rata-rata posttest 100, pada EYD nilai rata-rata pretest 51,14 dan nilai ratarata posttest 68,18 dan pada kalimat efektif nilai rata-rata pretest 67,05 dan nilai rata-rata posttest 72,73. Hasil uji hipotesis yang diperoleh dalam pembelajaran menulis berita adalah $T_{\text {hitung }}=5,83$ sedangkan $T(\alpha: n-1)=2,080$ pada tingkat kepercayaan $95 \%$ berarti $T_{\text {hitung }}>T(\alpha: n-1)$ maka $H 1$ diterima. Jadi, dapat disimpulkan bahwa metode inkuiri berpengaruh terhadap keterampilan menulis berita siswa kelas VIII SMPN 9 Payakumbuh.
\end{abstract}

Kata Kunci: Keterampilan Menulis, Berita, Metode Inkuiri

\section{INFLUENCE OF INQUIRY METHOD TO THE NEWS WRITING SKILL OF CLASS VIII STUDENTS OF SMPN 9 PAYAKUMBUH}

\begin{abstract}
The purpose of this research is to describe the influence of inquiry method to the news writing skill of class VIII students of SMPN 9 Payakumbuh viewed from the completeness of news elements, EYD, and effective sentences. This type of research is quantitative research. The method used is experiment. The sample of this research is the students of class VIII.2 SMP Negeri 9 payakumbuh. Secara general pretest average value of 71.5 and the average posttest value of 80.3. At the completeness of the news item the pretest average value is 96.59 and the mean value of posttest 100, on the EYD the pretest average value is 51.14 and the mean posttest score of 68.18 and in the effective sentence the average value of pretest 67, 05 and the average posttest score of 72.73. The result of hypothesis test obtained in news writing writing is $T_{\text {hitung }}=5.83$ whereas $T(\alpha: n-1)=2.080$ at 95\% level of trust means $T_{\text {hitung }}>T(\alpha: n-1)$ then $H 1$ is accepted. So, it can be concluded that the method of inquiry on the influence of writing skills news class VIII SMPN 9 Payakumbuh.
\end{abstract}

Keywords: Writing Skill, News, Inquiry Method 


\section{A. PENDAhuluan}

Diperoleh informasi bahwa keterampilan menulis berita siswa kelas VIII SMP Negeri 9 Payakumbuh belum mencapai Kriteria Ketuntasan Minimal (KKM). KKM yang ditetapkan adalah 75, sedangkan pencapaian hasil belajarnya $50 \%$ di bawah 75. Rendahnya hasil belajar menulis berita siswa di SMP Negeri 9 Payakumbuh disebabkan oleh beberapa faktor, yaitu: (1) kurangnya perhatian dan minat siswa dalam pembelajaran menulis berita; (2) kurangnya penguasaan materi pelajaran dalam menulis berita; dan (3) proses pembelajaran yang monoton, karena metode pembelajaran yang digunakan guru belum bervariasi.

Untuk memperbaiki kondisi di atas, guru perlu melakukan berbagai usaha di antaranya adalah melakukan pembaharuan pada metode pembelajaran. Salah satu metode pembelajaran yang dapat memberikan pengalaman yang bermakna bagi siswa adalah metode inkuiri. Dalam metode pembelajaran ini, siswa dituntut untuk berpikir secara kritis dan analitis untuk menemukan sendiri jawaban permasalahan yang dipertanyakan. Artinya, metode inkuiri memberikan kesempatan kepada siswa memecahkan sendiri permasalahan yang ada. Pembelajaran yang menuntut siswa untuk memecahkan sendiri permasalahan yang ditemukan dalam proses pembelajaran akan lebih bermakna dan menarik bagi siswa, agar siswa mau terlibat aktif dalam pembelajaran dan siswa mampu mengonstruksi sendiri pengetahuannya.

Armariena (2017:11) mengungkapkan keterampilan menulis merupakan kompetensi dasar yang harus dimilikik setiap siswa. Assegaff (1991:51), sebuah berita yang lazim harus memenuhi persyaratan yang dikenal dengan rumus $5 \mathrm{~W}+$ 1H yaitu singkatan dari: (what) apa, (who) siapa, (where) di mana, (when) kapan, (why) mengapa, dan (how) bagaimana. Selanjutnya, menurut Yurnaldi (1992: 22) berita hendaknya memiliki unsur-unsur sebagai berikut: (1) Who (siapa), yang kita jadikan bahan berita; (2) What (apa), peristiwa apa yang kita beritakan; (3) Where (di mana), peristiwa itu terjadi; (4) When (kapan), peristiwa itu berlangsung; (5) Why (mengapa), peristiwa itu terjadi; dan (6) How (bagaimana), jalannya peristiwa itu. 
Menurut Sabri (2005:12) inkuiri merupakan pendekatan mengajar yang berusaha meletakkan dasar dan mengembangkan cara berpikir ilmiah. Selanjutnya, menurut Gulo (2008:84) inkuiri berarti suatu rangkaian kegiatan belajar yang melibatkan secara maksimal seluruh kemampuan siswa untuk mencari dan menyelidiki secara sistematis, kritis, logis, analitis, sehingga mereka dapat merumuskan sendiri penemuannya dengan penuh percaya diri. Metode inkuiri merupakan rangkaian kegiatan pembelajaran yang menekankan pada proses berpikir secara kritis dan analitis untuk mencari dan menemukan sendiri jawaban dari suatu masalah yang dipertanyakan (Sanjaya, 2012:196).

Menurut Sabri (2005:13) ada lima tahapan yang ditempuh dalam melaksanakan metode inkuiri, yaitu (1) perumusan masalah untuk dipecahkan siswa; (2) menetapkan jawaban sementara atau hipotesis; (3) siswa mencari informasi yang diperlukan untuk menjawab permasalahan atau hipotesis; (4) menarik kesimpulan jawaban; dan (5) mengaplikasikan kesimpulan.

Berdasarkan uraian di atas, penulis akan melakukan penelitian dengan judul "Pengaruh Metode Inkuiri terhadap Keterampilan Menulis Berita Siswa Kelas VIII SMP Negeri 9 Payakumbuh”. Dengan menggunakan metode inkuiri ini diharapkan dapat menimbulkan perhatian dan minat siswa, sehingga siswa aktif dalam proses pembelajaran menulis berita.

\section{B. METODOLOGI PENELITIAN}

Jenis penelitian ini adalah penelitian kuantitatif. Metode penelitian yang digunakan dalam penelitian ini adalah metode eksperimen. Sugiyono (2012:72) menyatakan metode penelitian eksperimen dapat diartikan sebagai metode penelitian yang digunakan untuk mencari pengaruh perlakuan tertentu terhadap yang lain dalam kondisi yang terkendalikan. Metode eksperimen yang digunakan dalam penelitian ini adalah One-Group Pretest-Posttest Design. Pada desain ini terdapat pretest sebelum diberi perlakuan.

Populasi penelitian ini adalah seluruh siswa kelas VIII SMP Negeri 9 payakumbuh. Populasi terdiri dari delapan kelas yang berjumlah 171 siswa. Berdasarkan hasil perhitungan diperoleh X2 hitung $=5,61<14,07=\mathrm{X} 2(0,95: 7)$ 
maka H0 diterima. Ini berarti bahwa populasi homogen pada tingkat kepercayaan 95\%. Untuk pengambilan sampel, penulis menggunakan teknik cluster random sampling melalui undian (untung-untungan). Sampel penelitian berjumlah 22 orang siswa. Menurut Sugiyono (2012:82) dikatakan cluster random sampling karena pengambilan sampel populasi dilakukan secara acak tanpa memperhatikan strata yang ada dalam populasi itu.

Teknik pengumpulan data terdiri dari beberapa tahap yaitu, tahap persiapan, tahap pelaksanaan, dan athap akhir. Langkah-langkah dalam menganalisis data adalah sebagai berikut, (1) persiapan; (2) tabulasi; dan (3) penerapan data. Kegiatan dalam langkah persiapan adalah mengecek nama, mengecek kelengkapan data, dan mengecek macam isian. Kegiatan dalam langkah tabulasi antara lain adalah memberi skor terhadap item-item yang perlu diberi skor. Kegiatan dalam penerapan data adalah mengolah data yang diperoleh dengan menggunakan rumus-rumus atau aturan-aturan yang ada, sesuai dengan pendekatan penelitian atau desain yang diambil. Teknik analisis data dilakukan dengan langkah-langkah sebagai berikut memeriksa dan pemberian skor, menentukan nilai pretest dan posttest menentukan nilai rata-rata, mengklasifikasi hasil tes, dan menyimpulkan hasil analisis. Untuk menguji hipotesis, di dalam penelitian ini digunakan uji t.

\section{HASIL PENELITIAN DAN PEMBAHASAN}

\section{Keterampilan Menulis Berita Sebelum Menggunakan Metode Inkuiri (Pretest)}

Data hasil tes keterampilan menulis berita siswa secara umum sebelum menggunakan metode inkuiri terlihat pada tabel di bawah ini.

Tabel 1. Nilai Keterampilan Menulis Berita Sebelum Menggunakan Metode Inkuiri (Pretest) Secara Umum

\begin{tabular}{|c|c|c|c|c|}
\hline No & Kode Sampel & Skor & Nilai & Kualifikasi \\
\hline 1 & 001 & 10 & 83 & Baik \\
\hline 2 & 002 & 8 & 67 & Lebih dari cukup \\
\hline 3 & 003 & 11 & 92 & Baik sekali \\
\hline 4 & 004 & 9 & 75 & Lebih dari cukup \\
\hline 5 & 005 & 7 & 58 & Cukup \\
\hline
\end{tabular}




\begin{tabular}{|c|c|c|c|c|}
\hline $\begin{array}{c}\text { No } \\
6\end{array}$ & Kode Sampel & Skor & Nilai & Kualifikasi \\
\hline 7 & 006 & 10 & 83 & Baik \\
\hline 8 & 007 & 10 & 83 & Baik \\
\hline 9 & 008 & 9 & 75 & Lebih dari cukup \\
\hline 10 & 009 & 8 & 67 & Lebih dari cukup \\
\hline 11 & 010 & 9 & 75 & Lebih dari cukup \\
\hline 12 & 011 & 9 & 75 & Lebih dari cukup \\
\hline 13 & 012 & 9 & 75 & Lebih dari cukup \\
\hline 14 & 013 & 9 & 75 & Lebih dari cukup \\
\hline 15 & 014 & 7 & 58 & Cukup \\
\hline 16 & 015 & 7 & 58 & Cukup \\
\hline 17 & 016 & 7 & 58 & Cukup \\
\hline 18 & 017 & 9 & 75 & Lebih dari cukup \\
\hline 19 & 018 & 9 & 75 & Lebih dari cukup \\
\hline 20 & 019 & 8 & 67 & Lebih dari cukup \\
\hline 21 & 020 & 10 & 83 & Baik \\
\hline 22 & 021 & 7 & 58 & Cukup \\
\hline & 022 & 7 & 58 & Cukup \\
\hline & Jumlah & & $\mathbf{1 5 7 3}$ & \\
\hline
\end{tabular}

Berdasarkan tabel di atas, dapat diketahui siswa yang memperoleh nilai 92 berjumlah 1 orang siswa dengan kualifikasi baik sekali, siswa yang memperoleh nilai 83 berjumlah 4 orang siswa dengan kualifikasi baik, siswa yang memperoleh nilai 75 berjumlah 8 orang siswa dengan kualifikasi lebih dari cukup, siswa yang memperoleh nilai 67 berjumlah 3 orang siswa dengan kualifikasi lebih dari cukup, dan siswa yang memperoleh nilai 58 berjumlah 6 orang siswa dengan kualifikasi cukup.

Tabel 2. Rekapitulasi Hasil Tes Menulis Berita Siswa Perindikator

\begin{tabular}{|c|c|c|c|}
\hline No & Indikator & Jumlah Skor & Nilai \\
\hline 1 & Unsur berita & 85 & 96,59 \\
\hline 2 & EYD & 45 & 51,14 \\
\hline 3 & Kalimat efektif & 59 & 67,05 \\
\hline \multicolumn{2}{|c|}{ Jumlah } & $\mathbf{1 8 9}$ & $\mathbf{2 1 4 . 7 8}$ \\
\hline \multicolumn{2}{|c|}{ Rata-rata } & $\mathbf{6 3}$ & $\mathbf{7 1 . 5 9}$ \\
\hline
\end{tabular}

Berdasarkan tabel 1 dapat diketahui bahwa kemampuan siswa menulis berita memperoleh nilai rata-rata 71,59. Dari ketiga indikator nilai tertinggi diperoleh pada indikator penulisan unsur berita dengan jumlah nilai 96,59. Selanjutnya, untuk untuk indikator kalimat efektir dengan perolehan jumlah nilai 
67,05. Indikator penggunaan EYD memperoleh nilai 51,14. Dengan demikian keterampilan menulis berita siswa pada pretest masih di bawah KKM yang ditentukan yaitu 75.untuk lebih jelasnya dibawah ini akan ditampilkan distribusi frekuensi menulis berita untuk masing-masing indikator.

Tabel 3. Distribusi frekuensi Keterampilan Menulis Berita Sebelum Menggunakan Metode Inkuiri (Pretest) Berdasarkan indikator Kelengkapan Unsur-Unsur Berita

\begin{tabular}{|c|c|c|c|}
\hline No & X & F & XF \\
\hline 1 & 100 & 19 & 1900 \\
\hline 2 & 75 & 3 & 225 \\
\hline \multicolumn{2}{|c|}{ Jumlah } & N=22 & $\mathbf{2 F X = 2 1 2 5}$ \\
\hline \multicolumn{2}{|c|}{ Rata-Rata } & & $\mathbf{9 6 , 5 9}$ \\
\hline
\end{tabular}

Nilai rata-rata siswa adalah 96,59 dan berada pada kualifikasi sempurna. Dengan demikian, dapat dismpulkan bahwa keterampilan menulis berita sebelum menggunakan metode inkuiri (pretest) berdasarkan aspek kelengkapan unsurunsur berita $(5 \mathrm{~W}+1 \mathrm{H})$ berada pada tingkat penguasaan 96-100\% dengan kualifikasi sempurna

\section{Tabel 4. Distribusi Frekuensi Keterampilan Menulis Berita Sebelum} Menggunakan Metode Inkuiri (Pretest) Berdasarkan indikator EYD

\begin{tabular}{|c|c|c|c|}
\hline No & $\mathbf{X}$ & $\mathbf{F}$ & $\mathbf{X F}$ \\
\hline 1 & 100 & 1 & 100 \\
\hline 2 & 75 & 8 & 600 \\
\hline 3 & 50 & 4 & 200 \\
\hline 4 & 25 & 9 & 225 \\
\hline \multicolumn{2}{|c|}{ Jumlah } & $\mathbf{N = 2 2}$ & $\mathbf{\Sigma F X}=\mathbf{1 1 2 5}$ \\
\hline \multicolumn{2}{|c|}{ Rata-Rata } & & $\mathbf{5 1 , 1 4}$ \\
\hline
\end{tabular}

Nilai rata-rata siswa adalah 51,14 dan berada pada kualifikasi hampir cukup. Dengan demikian, dapat dismpulkan bahwa keterampilan menulis berita sebelum menggunakan metode inkuiri (pretest) berdasarkan indikator EYD (penggunaan huruf kapital) berada pada tingkat penguasaan 46-55\% dengan kualifikasi hampir cukup.

Tabel 5. Distribusi Frekuensi Keterampilan Menulis Berita Sebelum Menggunakan Metode Inkuiri (Pretest) Berdasarkan Penggunaan Kalimat Efektif

\begin{tabular}{|c|c|c|c|}
\hline No & X & F & XF \\
\hline 1 & 75 & 15 & 1125 \\
\hline 2 & 50 & 7 & 350 \\
\hline
\end{tabular}




\begin{tabular}{|c|c|c|c|}
\hline No & $\mathbf{X}$ & $\mathbf{F}$ & XF \\
\hline \multicolumn{2}{|c|}{ Jumlah } & $\mathrm{N}=22$ & $\Sigma F X=1475$ \\
\hline & & & 67,05 \\
\hline
\end{tabular}

Nilai rata-rata siswa adalah 67,05 dan berada pada kualifikasi lebih dari cukup. Dengan demikian, dapat dismpulkan bahwa keterampilan menulis berita sebelum menggunakan metode inkuiri (pretest) berdasarkan indikator penggunaan kalimat efektif berada pada tingkat penguasaan $67-75 \%$ dengan kualifikasi lebih dari cukup.

\section{Keterampilan Menulis Berita Siswa Setelah Menggunakan Metode Inkuiri (Posttest)}

Data hasil tes keterampilan menulis berita siswa secara umum setelah menggunakan metode inkuiri terlihat pada tabel di bawah ini.

Tabel 6. Nilai Keterampilan Menulis Setelah Menggunakan Metode Inkuiri (Posttest) Secara Umum

\begin{tabular}{|c|c|c|c|c|}
\hline No & Kode Sampel & Skor & Nilai & Kualifikasi \\
\hline 1 & 001 & 10 & 83 & Baik \\
\hline 2 & 002 & 9 & 75 & Lebih dari cukup \\
\hline 3 & 003 & 11 & 92 & Baik sekali \\
\hline 4 & 004 & 11 & 92 & Baik sekali \\
\hline 5 & 005 & 8 & 67 & Lebih dari cukup \\
\hline 6 & 006 & 11 & 92 & Baik sekali \\
\hline 7 & 007 & 11 & 92 & Baik sekali \\
\hline 8 & 008 & 9 & 75 & Lebih dari cukup \\
\hline 9 & 009 & 9 & 75 & Lebih dari cukup \\
\hline 10 & 010 & 11 & 92 & Baik sekali \\
\hline 11 & 011 & 9 & 75 & Lebih dari cukup \\
\hline 12 & 012 & 11 & 92 & Baik sekali \\
\hline 13 & 013 & 10 & 83 & Baik \\
\hline 14 & 014 & 8 & 67 & Lebih dari cukup \\
\hline 15 & 015 & 9 & 75 & Lebih dari cukup \\
\hline 16 & 016 & 10 & 83 & Baik \\
\hline 17 & 017 & 11 & 92 & Baik sekali \\
\hline 18 & 018 & 10 & 83 & Baik \\
\hline 19 & 019 & 9 & 75 & Lebih dari cukup \\
\hline 20 & 020 & 10 & 83 & Baik \\
\hline 21 & 021 & 8 & 67 & Lebih dari cukup \\
\hline 22 & 022 & 7 & 58 & Cukup \\
\hline \multicolumn{3}{|c|}{ Jumlah } & 1768 & \\
\hline \multicolumn{3}{|c|}{ Rata-Rata } & 80,36 & Baik \\
\hline
\end{tabular}


Berdasarkan tabel di atas, dapat diketahui siswa yang memperoleh nilai 92 berjumlah 7 orang siswa dengan kualifikasi baik sekali, siswa yang memperoleh nilai 83 berjumlah 5 orang siswa dengan kualifikasi baik, siswa yang memperoleh nilai 75 berjumlah 6 orang siswa dengan kualifikasi lebih dari cukup, siswa yang memperoleh nilai 67 berjumlah 3 orang siswa dengan kualifiikasi lebih dari cukup, dan siswa yang memperoleh nilai 58 berjumlah 1 orang siswa dengan kualifikasi cukup.

Tabel 7. Rekapitulasi Hasil Tes Menulis Berita Siswa Perindikator

\begin{tabular}{|c|l|c|c|}
\hline No & Indikator & Jumlah Skor & Nilai \\
\hline 1 & Unsur Berita & 88 & 100 \\
\hline 2 & EYD & 57 & 68,18 \\
\hline 3 & Kalimat Efektif & 64 & 72,73 \\
\hline \multicolumn{2}{|c|}{ Jumlah } & 209 & 240,91 \\
\hline \multicolumn{2}{|c|}{ Rata-rata } & 69,6 & 80,30 \\
\hline
\end{tabular}

Berdasarkan tabel di atas,dapat diketahui bahwa kemampuan siswa menulis berita memperoleh nilai rata-rata 80,30. Dari ketiga indikator nilai tertinggi diperoleh pada indikator penulisan unsur berita dengan jumlah nilai 100 . Selanjutnya, untuk untuk indikator kalimat efektir dengan perolehan jumlah nilai 72,73. Indikator penggunaan EYD memperoleh nilai 68,18. Dengan demikian setelah melakukan tes hasil belajar pada posttest keterampilan menulis berita siswa menjadi 80,30. Untuk lebih jelasnya di bawah ini akan ditampilkan distribusi frekuensi menulis berita untuk masing-masing indikator.

Table 8. Distribusi Frekuensi Keterampilan Menulis Berita Setelah Menggunakan Metode Inkuiri (Posttest) Berdasarkan indikator Kelengkapan Unsur Berita

\begin{tabular}{|l|c|c|c|}
\hline \multicolumn{1}{|c|}{ No } & $\mathbf{X}$ & $\mathbf{F}$ & $\mathbf{X F}$ \\
\hline 1 & 100 & 22 & 2200 \\
\hline Jumlah & & $\mathrm{N}=22$ & $\mathbf{\Sigma F X}=\mathbf{2 2 0 0}$ \\
\hline Rata-rata & & & 100 \\
\hline
\end{tabular}

Nilai rata-rata siswa adalah 100 dan berada pada kualifikasi sempurna. Dengan demikian, dapat dismpulkan bahwa keterampilan menulis berita setelah menggunakan metode inkuiri (posttest) berdasarkan aspek kelengkapan unsurunsur berita $(5 \mathrm{~W}+1 \mathrm{H})$ berada pada tingkat penguasaan 96-100\% dengan kualifikasi sempurna. 
Tabel 9. Distribusi frekuensi Keterampilan Menulis Berita Setelah Menggunakan Metode Inkuiri (Posttest) Berdasarkan indikator EYD

\begin{tabular}{|c|c|c|c|}
\hline No & $\mathbf{X}$ & $\mathbf{F}$ & $\mathbf{X f}$ \\
\hline 1 & 100 & 7 & 700 \\
\hline 2 & 75 & 6 & 450 \\
\hline 3 & 50 & 5 & 250 \\
\hline 4 & 25 & 4 & 100 \\
\hline Jumlah & & $\mathrm{N}=22$ & $\mathbf{\Sigma F X}=\mathbf{1 5 0 0}$ \\
\hline Rata-rata & & & 68,18 \\
\hline
\end{tabular}

Nilai rata-rata siswa adalah 68,18 dan berada pada kualifikasi lebih dari cukup. Dengan demikian, dapat dismpulkan bahwa keterampilan menulis berita setelah menggunakan metode inkuiri (posttest) berdasarkan aspek EYD berada pada tingkat penguasaan 66-75\% dengan kualifikasi lebih dari cukup.

Tabel 10. Distribusi Frekuensi Keterampilan Menulis Berita Setelah Menggunakan Metode Inkuiri (Posttest) Berdasarkan Penggunaan Kalimat Efektif

\begin{tabular}{|c|c|c|c|}
\hline No & $\mathbf{X}$ & $\mathbf{F}$ & $\mathbf{X f}$ \\
\hline 1 & 75 & 20 & 1500 \\
\hline 2 & 50 & 2 & 100 \\
\hline Jumlah & & $\mathrm{N}=22$ & $\mathbf{\Sigma F X}=\mathbf{1 6 0 0}$ \\
\hline Rata-rata & & & 72,73 \\
\hline
\end{tabular}

Nilai rata-rata siswa adalah 72,73 dan berada pada kualifikasi lebih dari cukup. Dengan demikian, dapat dismpulkan bahwa keterampilan menulis berita setelah menggunakan metode inkuiri (posttest) berdasarkan indikator penggunaan kalimat efektif berada pada tingkat penguasaan 66-75\% dengan kualifikasi lebih dari cukup.

Dapat disimpulkan bahwa metode inkuiri berpengaruh terhadap keterampilan menulis berita siswa kelas VIII SMP Negeri 9 Payakumbuh. Secara umum nilai rata-rata pretest 71,5 dengan kualifikasi lebih dari cukup dan rata-rata posttest 80,36 dengan kualifikasi baik. Perbandingan penggunaan metode inkuiri pada masing-masing indikator penilaian berita dalam pretest dan posttest dapat dilihat pada gambar berikut ini. 


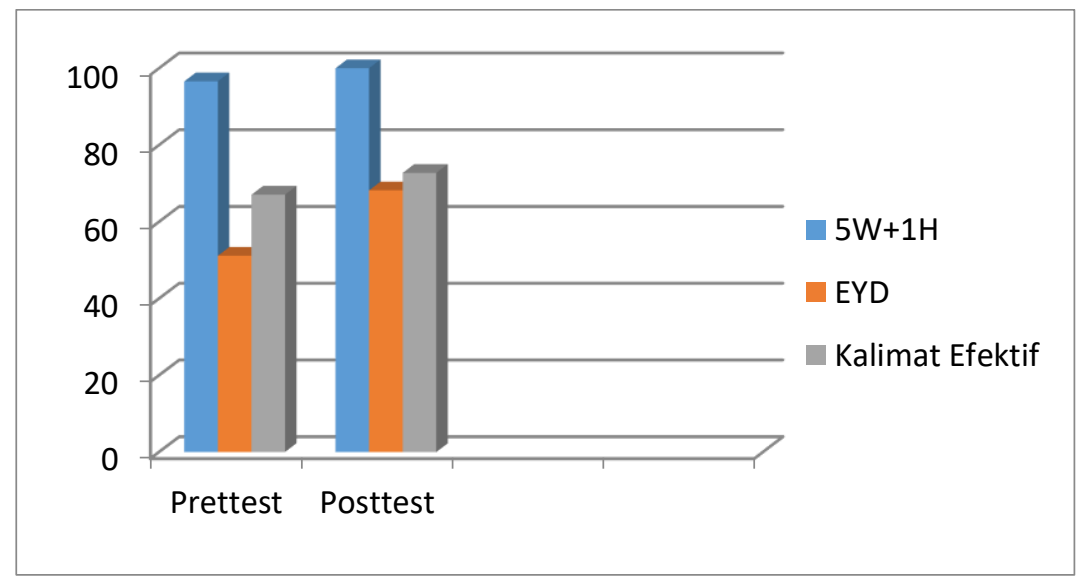

\section{Gambar 1. Histogram Hasil Prettest dan Posttest Menulis Berita Siswa}

Berdasarkan gambar di atas dapat diketahui pengaruh penggunaan metode inkuiri dapat dilihat dari meningkatnya nilai rata-rata setiap aspek yang dinilai, yaitu kelengkapan unsur berita $(5 \mathrm{~W}+1 \mathrm{H})$ nilai rata-rata pretest 96,59 dan ratarata nilai posttest 100, EYD nilai rata-rata pretest 51,14 dan nilai rata-rata posttest 68,18 , dan kalimat efektif nilai rata-rata pretest 67,05 dan nilai rata-rata postest 72,73 . Perbandingan

\section{Pengaruh Penerapan Metode Inkuiri Terhadap Keterampilan Menulis Berita Siswa}

Tabel 11. Uji Hipotesis Pengaruh Metode Inkuiri Terhadap Keterampilan Menulis Berita Siswa Secara Umum

\begin{tabular}{|c|l|l|c|c|}
\hline \multirow{2}{*}{ No } & \multirow{2}{*}{ Parameter } & \multicolumn{2}{|c|}{ Kelas Sampel } & \multirow{2}{*}{ Keterangan } \\
\cline { 3 - 4 } & & Pretest & H1diterima Posttest & \\
\hline 1 & Rata-rata & 71,5 & 80,36 & \\
\hline 2 & Uji hipotesis & $\begin{array}{l}\text { Thitung }=5,83 \\
\mathrm{~T}(\alpha: n-1)=2,080\end{array}$ & \\
\hline
\end{tabular}

Berdasarkan uji hipotesis diperoleh hasil Thitung $=5,83$, sedangkan $\mathrm{T}(\alpha: \mathrm{n}$ 1) $=2,080$ sehingga Thitung $>\mathrm{T}(\alpha: \mathrm{n}-1)$ artinya hipotesis H1 diterima. Jadi dapat dinyatakan bahwa penggunaan metode inkuiri berpengaruh terhadap keterampilan siswa dalam menulis berita.

Hasil uji hipotesis menunjukkan hasil belajar menulis berita secara umum dengan Thitung $=5,83$ sedangkan $\mathrm{T}(\alpha: \mathrm{n}-1)=2,080$ pada tingkat kepercayaan $95 \%$ berarti Thitung $>\mathrm{T}(\alpha: \mathrm{n}-1)$, maka $\mathrm{H} 1$ diterima. Berarti pengunaan metode inkuiri 
pada pembelajaran menulis berita berpengaruh positif terhadap keterampilan siswa dalam menulis berita.

\section{PEMBAHASAN}

Metode inkuiri merupakan rangkaian kegiatan pembelajaran yang menekankan pada proses berpikir secara kritis dan analitis untuk mencari dan menemukan sendiri jawaban dari suatu masalah yang dipertanyakan (Sanjaya, 2012: 196). Hasil analisis data menunjukkan bahwa metode inkuiri berpengaruh terhadap keterampilan menulis berita siswa kelas VIII SMPN 9 payakumbuh dengan nilai rata-rata pretest 71,5 berada pada kualifikasi lebih dari cukup dan nilai rata-rata posttest 80,36 berada pada kualifikasi baik. Faktor yang mempengaruhi meningkatnya nilai siswa adalah metode inkuiri berhasil diterapkan, sehingga siswa aktif dalam proses pembelajaran.

Hasil analisis data menunjukkan bahwa metode inkuiri berpengaruh terhadap keterampilan menulis berita siswa kelas VIII SMPN 9 payakumbuh berdasarkan aspek kelengkapan unsur-unsur berita $(5 \mathrm{~W}+1 \mathrm{H})$ dengan nilai ratarata pretest 96,59 berada pada kualifikasi sempurna dan nilai rata-rata posttest 100 berada pada kualifikasi sempurna.

Hasil analisis data menunjukkan bahwa metode inkuiri berpengaruh terhadap keterampilan menulis berita siswa kelas VIII SMPN 9 Payakumbuh berdasarkan aspek pengunaan huruf kapital dengan nilai rata-rata pretest 51,14 berada pada kualifikasi hampir cukup dan nilai rata-rata posttest 68,18 berada pada kualifikasi lebih dari cukup. Berdasarkan aspek pengunaan kalimat efektif dengan nilai rata-rata pretest 67,05 berada pada kualifikasi lebih dari cukup dan nilai rata-rata posttest 72,73 berada pada kualifikasi lebih dari cukup.

\section{SIMPULAN}

Berdasarkan hasil penelitian setelah dilakukan analisis data tentang pengaruh metode inkuiri terhadap keterampilan menulis berita siswa dapat disimpulkan sebagai berikut. 
1. Metode inkuiri berpengaruh terhadap keterampilan menulis berita siswa kelas VIII SMPN Payakumbuh secara umum nilai rata-rata pretest 71,5 dengan kualifikasi lebih dari cukup dan rata-rata posttest 80,36 dengan kualifikasi baik.

2. Pengaruh penggunaan metode inkuiri dapat dilihat dari meningkatnya nilai rata-rata setiap aspek yang dinilai, yaitu kelengkapan unsur berita $(5 \mathrm{~W}+1 \mathrm{H})$ nilai rata-rata pretest 96,59 dan rata-rata nilai posttest 100, EYD (penggunaan huruf kapital) nilai rata-rata pretest 51,14 dan nilai rata-rata posttest 68,18 , dan kalimat efektif nilai rata-rata pretest 67,05 dan nilai rata-rata postest 72,73 .

Hasil uji hipotesis menunjukkan hasil belajar menulis berita secara umum dengan $\mathrm{T}_{\text {hitung }}=5,83$ sedangkan $\mathrm{T}_{(\alpha: \mathrm{n}-1)}=2,080$ pada tingkat kepercayaan $95 \%$ berarti $\mathrm{T}_{\text {hitung }}>\mathrm{T}_{(\alpha: n-1)}$, maka $\mathrm{H}_{1}$ diterima. Berarti pengunaan metode inkuiri pada pembelajaran menulis berita berpengaruh positif terhadap keterampilan siswa dalam menulis berita.

\section{DAFTAR PUSTAKA}

Armariena, D. N. (2017). Penulisan Narasi Mahasiswa dengan Metode Copy The Master dalam Menghidupkan Karakter, Perilaku, dan Konflik Tokoh. Prosiding Dosen Universitas PGRI Palembang Edisi 9, 10-19. Palembang: Universitas PGRI Palembang.

Assegaff, H. Dja'far. (1991). Jurnalistik Masa Kini. Bandung: Balai Aksara.

Budyatna, Muhammad. (2007). Jurnalistik Teori dan Praktik. Bandung: Remaja Rosdakarya.

Gulo, W. (2008). Strategi Belajar Mengajar. Jakarta: Grasindo.

Sabri, Ahmad. (2005). Strategi Belajar Mengajar Micro Teaching. Jakarta: Quatum Teaching.

Sanjaya, Wina. (2012). Strategi Pembelajaran: Berorientasi Standar Proses Pendidikan. Jakarta: Kencana Prenada Media Group.

Sugiyono. (2012). Metode Penelitian Kuantitatif, Kualitatif R dan D. Bandung: Alfabeta Bandung. 